\section{US acts to lengthen term of patents to help biotechnology}

[WASHINGTON] In a boost to the US biotechnology industry, the House of Representatives last week approved a bill that would reverse the reduction in patent protection that companies say they are facing as a result of 1994 legislation that implemented the General Agreement on Trade and Tariffs (GATT).

The bill, sponsored by Congressman Howard Coble, (Republican, North Carolina), passed by 376 votes to 43 . It aims to mitigate the effects of a GATT provision that changed patent terms to 20 years from the date a patent application is filed. Patent protection was previously granted for $\mathbf{1 7}$ years from the date a patent was issued.

The biotechnology industry says the 1994 change shortened the terms of its patents, as biotechnology inventions usually take longer to win approval at the Patent and Trademark Office (PTO) than other inventions, which take less than two years on average.

Under the bill - the American Inventors Protection Act - inventors would be compensated by having a day added to the patent term for each day over three years that it takes the PTO to grant a patent (providing that the delay is not the applicant's fault). This would effectively guarantee a 17 -year patent term from the date a patent is issued.

Chuck Ludlam, the vice-president for government relations at the Biotechnology Industry Organization, says it is "an incredibly important provision" to restore patent terms "that otherwise would be eroded".

The bill also requires the PTO to publish after 18 months any patent applications that are already published in other countries. Industry had lobbied for publication of all applications, not just those published abroad. It says that publication helps companies to avoid pursuing research and development in areas already staked out by others.

But independent inventors are opposed to this provision, arguing that companies might intimidate them or steal their inventions if they are published before patents are granted.

Although the bill has not been introduced in the Senate, Jeanne Lopatto, a spokeswoman for the judiciary committee, says that the committee's chairman, Senator Orrin Hatch (Republican, Utah), "is committed to patent reform" and will address the issue in Congress.

The bill does not address the issue of 'first to file' versus 'first to invent', which divides the countries of the European Commission from the United States (see Nature 397, 457; 1999). Some European countries were seeking a US shift on this in exchange for accepting a period of grace on patent applications in Europe.

Meredith Wadman

\title{
French anger over plan to back British synchrotron
}

[PARIS] Last week's decision by the French government to support the construction of a new synchrotron facility in Britain rather than France (see Nature 400, 489; 1999) has generated a strong backlash in the French scientific community.

The day after the announcement, Robert Comes, director of the Laboratoire de l'Utilization du Rayonnement Électromagnétique (LURE) at Orsay, south of Paris, and its two deputy directors, Jean Daillant and Abderrahmane Tadjeddine, issued a statement saying they would refuse to cooperate with the plan.

Before last week's decision there had been hopes that the French government would replace the ageing facilities at LURE with Soleil, a 2.15-GeV third-generation synchrotron (see Nature 392, 114; 1998).

One of the main complaints is that Diamond, the planned British 3-GeV synchrotron, will fall short of the needs of the 2,000 French scientists who rely on such facilities for their experiments. "From a scientific point of view, the common project will at best fill one-quarter to one-third of French needs, and probably about one-half of British needs," the LURE directors say.

Their complaints are echoed by members of a joint committee between the Atomic Energy Commission and the Centre National de Recherche Scientifique which was set up to consider synchrotron radiation in France. Also, SNCS, the main trade union representing scientists, and scientists at Orsay have expressed anger at the decision made by Claude Allègre, the minister of education, research and technology.

Other opponents of Allègre's decision include politicians from six regions that were eager to sponsor half the cost of building a synchrotron facility in their district. They are seeing thousands of potential jobs disappear, together with the economic boost and prestige of such a large-scale facility.

French scientists have pushed for Soleil for more than a decade. But Allègre announced on 2 August that, instead of going ahead with it, the government would give an estimated FF350 million (US\$56 million) over seven years towards Diamond, and FF60 to FF80 million a year to its operating costs.

"From its arrival, the French government has made known that it wished all future large scientific facilities to be carried out on a European scale," Allègre stated.

Ironically, only the Greens of the Ile-deFrance welcomed the decision. "The European partnership and the pooling of facilities, finances and skills represent the future," says Michel Michelon, president of the

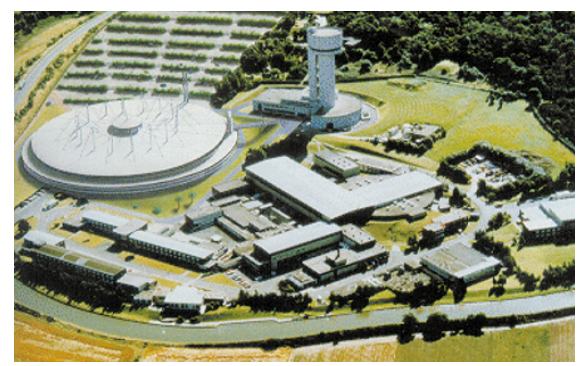

Rough Diamond? French scientists say new UK synchrotron (above) will not meet their needs.

national and regional development committee for the Ile-de-France council.

Allègre's opponents disagree with the cost analysis said to be behind his decision. "It's not at all obvious that the English solution is less expensive," says Yves Farge, a former ministerial adviser and former head of research at Pechiney, who wrote a detailed report on Soleil.

Farge and other scientists say that Allègre based his decision on a report drawn up by one of his advisers, Paul Clavin, who is not a known expert in the field. "What needs to be done is to make the report public," Farge says.

Clavin admits that he is not an expert on synchrotrons, but argues that the costs of Soleil would be "excessive for France", adding that its initial designs did not focus sufficiently on the needs of structural biology. "Also, it would be irresponsible to let the chance of collaborating with the British pass by."

Yves Petroff, director-general of the European Synchrotron Radiation Facility at Grenoble, who was asked to review Clavin's document by the minister, says: "Basically, everything is incorrect. I have no objection to cooperating with the British or any other country, but, based on this report, that is totally irrational."

Petroff argues that Allègre underestimates the cost of participating in the British synchrotron, and says that France will eventually end up spending the same money that it would have done in building Soleil.

Scientists and politicians say they are also upset that Allègre announced the decision at the beginning of August, when many French scientists are on vacation. Allègre is expected to explain his decision in more detail at a meeting scheduled for September.

Jean-Paul Huchon, president of the Ilede-France region, had called for the meeting with Allègre. Staff at LURE and other groups will then assess their course of action. Until then, says Chantal Damais of the SNCS's national bureau, there will be little activity. "The scientists are extremely indignant but they are at the beach." Heather McCabe 